\title{
Pengaruh Ukuran Embriozigot terhadap Regenerasi Beberapa KIon Kakao
}

\author{
Sholeh Avivi ${ }^{\left.{ }^{*}\right)}$, Didik Pudji Restanto ${ }^{1)}$, dan Tri Widyastuti ${ }^{2)}$ \\ 1)Jurusan Agroteknologi, Fakultas Pertanian, Universitas Jember, Jember 68121 \\ 2)Pascasarjana, Jurusan Agronomi, Universitas Jember, Jember 68121 \\ Diterima 13-09-2010 Disetujui 06-04-2011
}

\begin{abstract}
This sesearch identified the responses of size of zygotic embryo of cocoa and to identify the responses of cocoa clone types toward ability to produce somatic embryo. The research was designed by Completely Randomized Factorial Design within five replications. The first factors were the sizes of used explants, namely small (2-5 mm), average (6-9 mm) and big (10-15 mm). The second factors were cocoa clones, namely RCC 72, Sca 6, KW 162, KW 163 and KW 165. The result showed that the best explant was the small size $(2-5 \mathrm{~mm})$ of cocoa zygotic embryo. It had significantly on number of rooting embryos and number of embryos with buds on rooting media. Clone RCC 72 was the most responsive clone and could generate to be plantlet. Clone KW 165 performed the lowest response.
\end{abstract}

Keywords : cocoa, regeneration, size of embryos

\section{PENDAHULUAN}

Program revitalisasi di tahun 2010 diperkirakan membutuhkan sekitar 50 juta bahan tanam untuk peremajaan, rehabilitasi dan perluasan areal. Ditambah dengan kebutuhan di luar revitalisasi, maka total kebutuhan bahan tanam kakao di tahun 2010 dapat mencapai 80 juta bahan tanam. sedangkan dengan teknik konvensional, penyediaan bahan tanam hanya bisa memenuhi sekitar 35-50 juta per tahun (Anonim, 2008; Wahyudi et al., 2008). Untuk memenuhi kebutuhan tersebut perlu dicari suatu alternatif metode perbanyakan yang baru. Salah satu alternatif adalah dengan teknik kultur jaringan.

Kultur jaringan tanaman kakao melalui teknik embriogenesis somatik sudah dikembangkan oleh beberapa peneliti (Funek et al., 2007; Rojas et al., 2008; Issali et al., 2009; Issali et al., 2010). Teknik ini dapat memperbanyak tanaman kakao secara klonal (Winarsih et al., 2002). Metode perbanyakan klonal, walaupun lebih sulit, dapat menjadi alternatif terbaik karena dianggap akan menghasilkan bibit yang seragam dan kualitasnya sama dengan induknya (Mark \& Maximova, 2000; Alemanno et al., 2007). Perbanyakan klonal kakao dengan teknik kultur jaringan dapat menggunakan eksplan bunga dan embrio zigotik. Salah satu faktor yang berperan dalam perbanyakan dengan eksplan embrio zigot adalah umur embrio yang digunakan sebagai eksplan. Di diduga dengan semakin kecilnya ukuran embrio jaringan meristematiknya semakin muda. Proses regenerasi dari embrio zigotik menjadi planlet telah dilaporkan oleh Lopez-Baez et al., (1993). Planlet berhasil didapatkan dari jaringan embrio zigotik muda umur 120-150 hari sejak pembungaan.

Penelitian ini bertujuan untuk melihat pengaruh ukuran embrio zigot dari beberapa klon kakao terhadap daya regenerasi eksplan hingga menjadi planlet (di duga dengan semakin kecilnya embrio zigot jaringannya semakin muda). Dari hasil penelitian ini diharapkan dapat diperoleh metode regenerasi klon-klon unggul kakao dengan ukuran eksplan embrio zigotik yang paling baik.

\section{BAHAN DAN METODE}

Penelitian disusun menurut rancangan acak lengkap faktorial dengan lima ulangan. Faktor pertama adalah 5 klon kakao terdiri dari RCC 72, Sca 6, KW 162, KW 163 dan KW 165. Faktor kedua adalah 3 ukuran embrio yaitu kecil (2-5 mm), sedang (6-9 mm) dan besar (10-15 mm).

Bahan tanam yang digunakan dalam embriogenesis somatik adalah embrio zigotik kakao dari klon RCC 72, Sca 6, KW 162, KW 163 dan KW 165. Embrio zigotik diisolasi dari bakal biji buah kakao 
umur 120-150 hari. Klon diperoleh dari Kebun Koleksi Kakao milik Pusat Penelitian Kopi dan Kakao Indonesia.

Alat-alat yang digunakan adalah LAF, autoclave, oven, kompor gas, kulkas, neraca analitik, $\mathrm{pH}$ meter, bunsen, pisau, beaker glass, erlenmeyer, pipet, scalpel, penggojok, botol kultur. Tahapan regenerasi terdiri dari tahapan inisiasi, induksi, multiplikasi, perakaran, dan pra-aklimatisasi.

Tahap Inisiasi dan Induksi. Embrio dengan ukuran berbeda sesuai perlakuan ditanam dalam media inisiasi yaitu media dasar B5 yang dimodifikasi dengan

${ }^{-1}$, Kinetin $2 \mathrm{mgl}^{-1}$, air kelapa $100 \mathrm{ml} \mathrm{l}^{-1}$, sukrosa $30 \mathrm{~g} \mathrm{l}^{-1}$ dan phytage/ $2 \mathrm{~g} \mathrm{l}^{-1}$. Kultur disimpan pada ruang gelap suhu $26-28^{\circ} \mathrm{C}$.

Tahap Multiplikasi. Embrio somatik yang terbentuk kemudian dipindah ke media multiplikasi untuk proses perbanyakan. Media multiplikasi terdiri atas media dasar B5 yang diperkaya dengan NAA $0,01 \mathrm{mgl}^{-1} ; 2$ iP $0,3 \mathrm{mgl}^{-1}$ arang aktif (charcoal) $1 \mathrm{~g} \mathrm{l}^{-1}$, glukosa $40 \mathrm{~g} \mathrm{l}^{-1}$ dan phytagel $2 \mathrm{~g} \mathrm{l}^{-1}$.

Tahap Perakaran. Embrio fase kotiledon kemudian dipindahkan ke media perakaran untuk membentuk tunas dan akar yang terdiri atas media dasar B5 dilengkapi dengan glukosa $10 \mathrm{~g} \mathrm{l}^{-1}$ dan arang aktif $0,3 \mathrm{~g} \mathrm{l}^{-1}$ yang dipadatkan dengan phytagel $2 \mathrm{~g} \mathrm{l}^{-1}$ tanpa zat pengatur tumbuh.

Tahap Pra Aklimatisasi. Plantlet dengan tinggi 4-5 $\mathrm{cm}$ dan mempunyai 1 pasang daun dikeluarkan dari botol kultur, dicuci dengan air kemudian direndam dalam larutan fungisida Dithane $0,2 \%$ selama 1 menit. Setelah itu plantlet ditanam dalam gelas aqua yang berisi medium steril campuran tanah, pupuk kandang dan pasir dengan perbandingan 1:1:1.

Parameter pengamatan yang diamati adalah: ratarata persentase jumlah eksplan berkalus (4 MST), persentase jumlah eksplan dengan Kalus Embriogenik (25 MST), rata-rata kedinian pembentukan embrio somatik (1-26 MST), persentase eksplan menghasilkan embrio (25 MST), jumlah embrio somatik per eksplan (25 MST), rata-rata jumlah akar dan panjang akar
(32 MST), Rata-rata jumlah daun, jumlah tunas, panjang daun dan tinggi tanaman (32 MST). Data dianalisis dengan uji sidik ragam yang dilanjutkan dengan uji BNJ pada taraf kepercayaan $95 \%$.

\section{HASIL DAN PEMBAHASAN}

Tahap Inisiasi dan Induksi. Ukuran eksplan tidak berpengaruh nyata terhadap persentase jumlah eksplan berkalus pada tahap inisiasi, tetapi semakin kecil ukuran eksplan yang dipakai, cenderung semakin tinggi persentase jumlah eksplan berkalus. Ukuran kecil menghasilkan rata-rata persentase tertinggi $(24,8 \%)$ dibandingkan dengan ukuran sedang (22,2\%) dan besar $(20,8 \%)$. Hal ini menunjukkan dengan semakin kecilnya ukuran embriozigot potensi perubahan eksplan menjadi kalus semakin besar.

Tabel 1, menunjukkan adanya perbedaan respon antar 5 jenis klon (eksplan) yang dikulturkan terhadap jumlah eksplan berkalus pada 4 minggu setelah tanam (MST), tetapi tidak untuk faktor ukuran eksplan. Pada umumnya hampir setiap klon dan jaringan tanaman kakao mempunyai respon yang baik dalam pengkalusan. Hal ini disebabkan kandungan hormon endogen dalam jaringan tanaman kakao cukup untuk menginduksi kalus (Winarsih et al., 2003). Demikian juga embrio zigotik dari 5 klon yang diuji, seluruhnya menghasilkan kalus dengan rata-rata $22,6 \%$ per eksplan. Respon paling tinggi dari 5 jenis klon yang diuji adalah klon RCC 72 dengan persentase jumlah eksplan berkalus sebesar $45,8 \%$ yang berbeda nyata dengan klon KW 165, tetapi tidak berbeda nyata dengan klon KW 163, KW 162 dan Sca 6. Persentase jumlah eksplan berkalus paling kecil adalah jenis klon KW 165 $(2,9 \%)$. Adanya perbedaan respon ini menunjukkan bahwa setiap genotipe mempunyai kandungan zat pengatur tumbuh endogen yang berbeda dan perbedaan genetis antar klon (Priyono et al., 2000). Perbedaan itu juga mungkin disebabkan karena adanya respon yang berbeda terhadap gula yang ditambahkan (Tan \& Furtek (2003).

Tabel 1. Rata-rata persentase jumlah eksplan berkalus (4 MST)

\begin{tabular}{|c|c|c|c|c|c|}
\hline \multirow[b]{2}{*}{ Ukuran embrio } & \multicolumn{5}{|c|}{ Jenis eksplan } \\
\hline & Sca 6 & KW 162 & KW 163 & KW 165 & RCC 72 \\
\hline Besar & 26,0 & 21,2 & 14,4 & 2,0 & 40,4 \\
\hline Sedang & 26,8 & 32,0 & 3,6 & 1,6 & 47,0 \\
\hline Kecil & 27,2 & 29,2 & 12,2 & 5,2 & 50,0 \\
\hline Rata-rata & $26,7 \mathrm{~b}$ & $27,5 \mathrm{~b}$ & $10,1 \mathrm{ab}$ & $2,9 a$ & $45,8 \mathrm{bc}$ \\
\hline
\end{tabular}

Keterangan: angka-angka pada kolom yang diikuti oleh huruf yang sama menunjukkan berbeda tidak nyata pada uji BNJ $5 \%$ 
Setelah 4 minggu di media inisiasi, eksplan yang telah berkalus dipindah ke media induksi untuk mengamati jumlah eksplan dengan kalus embriogenik, kedinian pembentukan embrio somatik dan jumlah eksplan menghasilkan embrio. Perkembangan kalus pada media induksi diikuti dengan terbentuknya embrio somatik secara langsung maupun tidak langsung (melewati fase kalus), sehingga dalam eksplan yang sama dapat tumbuh kalus maupun embrio somatik. Menurut Oliveira Santos et al., (2005), proses somatik embryogenesis dipengaruhi oleh gen SERK. Gen SERK berekspresi tinggi pada kalus yang mengalami inisiasi membentuk kalus embriogenik.

Tabel 2 menunjukkan adanya perbedaan respon antar 5 jenis klon terhadap jumlah eksplan dengan kalus embriogenik. Lima jenis klon kakao yang diuji, menghasilkan kalus embriogenik dengan jumlah ratarata $1,4 \%$ per eksplan. Respon paling tinggi dari 5 jenis klon kakao adalah klon RCC 72 dengan persentase jumlah eksplan embriogenik sebesar 2,3\% yang berbeda nyata dengan klon KW 165 dan KW 163, tetapi tidak berbeda nyata dengan klon KW 162 dan Sca 6 . Persentase jumlah eksplan embriogenik paling rendah diperoleh pada klon KW 165 (0,2\%). Urutan respon klon dimulai dari yang paling tinggi adalah RCC 72, SCA 6, KW 162, KW 163 dan KW 165. sedangkan untuk faktor ukuran, semua ukuran eksplan tidak berpengaruh nyata terhadap persentase jumlah eksplan dengan kalus embriogenik. Adanya perbedaan pada perlakuan tertentu disebabkan karena perlakuan zat pengatur tumbuh yang ditambahkan ke dalam media. Perbedaan respon antarklon ini diduga disebabkan perbedaan faktor endogen karena sifat genetis.
Eksplan dengan kalus embriogenik yang terbentuk pada media induksi kemudian disubkultur kembali pada media induksi yang komposisinya sama dengan media inisiasi tetapi tanpa zat pengatur tumbuh untuk merangsang pembentukan embriogenesis somatik dari tiap eksplan yang ditanam. Hasil analisis sidik ragam menunjukkan bahwa terdapat interaksi yang nyata antara faktor jenis eksplan dan faktor ukuran eksplan terhadap waktu yang dibutuhkan untuk mengawali pembentukan embrio somatik.

Tabel 3 menunjukan bahwa terdapat interaksi antara jenis eksplan dan ukuran eksplan terhadap kedinian pembentukan embrio somatik per eksplan. Dengan demikian pengaruh ukuran eksplan baru nampak pada tahap induksi. Klon RCC 72 dengan ukuran eksplan sedang memberikan respon paling cepat dalam mengawali kedinian pembentukan embrio somatik. Waktu yang dibutuhkan untuk menghasilkan embrio adalah 6,0 MST, yang berbeda nyata dengan klon KW 163 ukuran sedang (22,4 MST), klon KW 165 ukuran besar (24,4 MST), klon KW 165 ukuran sedang (25,6 MST) dan klon KW 165 ukuran kecil (21,2 MST). Waktu paling lama yang dibutuhkan untuk mengawali pembentukan embrio somatik per eksplan terdapat pada klon KW 165 ukuran sedang yaitu pada 25,6 MST. Semakin tinggi persentase kalus embriogenik maka semakin besar dan cepat dalam menghasilkan embrio somatik (Winarsih et al., 2003).

Tiga minggu setelah eksplan embriogenik disubkultur ke media induksi, ke-5 jenis klon kakao memberikan respon yang berbeda-beda terhadap waktu yang dibutuhkan untuk mengawali pembentukan embrio somatik per eksplan. Dari masing-masing jenis eksplan

Tabel 2. Persentase jumlah eksplan dengan kalus embriogenik (25 MST)

\begin{tabular}{|c|c|c|c|c|c|}
\hline \multirow[b]{2}{*}{ Ukuran Embrio } & \multicolumn{5}{|c|}{ Jenis Eksplan } \\
\hline & Sca 6 & KW 162 & KW 163 & KW 165 & RCC 72 \\
\hline Besar & 1,6 & 1,3 & 1,2 & 0,2 & 2,1 \\
\hline Sedang & 1,9 & 2,0 & 0,2 & 0,04 & 2,3 \\
\hline Kecil & 2,2 & 1,3 & 0,8 & 0,4 & 2,5 \\
\hline Rata-rata & $1,9 \mathrm{bc}$ & $1,5 a b c$ & $1,1 \mathrm{ab}$ & $0,2 \mathrm{a}$ & $2,3 \mathrm{c}$ \\
\hline
\end{tabular}

Keterangan: angka-angka pada kolom yang diikuti oleh huruf yang sama menunjukkan berbeda tidak nyata pada uji BNJ $5 \%$

Tabel 3. Rata-rata kedinian pembentukan embrio somatik (1-26 MST)

\begin{tabular}{|c|c|c|c|c|c|}
\hline \multirow[b]{2}{*}{ Ukuran Embrio } & \multicolumn{5}{|c|}{ Jenis Eksplan } \\
\hline & Sca 6 & KW 162 & KW 163 & KW 165 & RCC 72 \\
\hline Besar & $10,6 \mathrm{c}$ & $10,2 \mathrm{c}$ & $12,2 \mathrm{bc}$ & $24,4 \mathrm{a}$ & $7,2 \mathrm{c}$ \\
\hline Sedang & $7,6 \mathrm{c}$ & $7,4 \mathrm{c}$ & $22,4 \mathrm{a}$ & $25,6 \mathrm{a}$ & $6,0 \mathrm{c}$ \\
\hline Kecil & $7,6 \mathrm{c}$ & $8,6 \mathrm{c}$ & $12,6 \mathrm{bc}$ & $21,2 a b$ & $7,0 \mathrm{c}$ \\
\hline
\end{tabular}

Keterangan: angka-angka pada kolom yang diikuti oleh huruf yang sama menunjukkan berbeda tidak nyata pada uji BNJ $5 \%$ 
dan ukuran eksplan yang diuji, rata-rata menghasilkan embrio somatik dari setiap eksplan.

Tabel 4 menunjukkan bahwa terdapat interaksi antara jenis eksplan dan ukuran eksplan terhadap persentase eksplan menghasilkan embrio. Klon Sca 6 memberikan respon yang paling baik dengan persentase eksplan menghasilkan embrio rata-rata sebesar $100 \%$. Hal ini menunjukkan bahwa klon Sca 6 dengan ukuran embrio zigotik besar, sedang dan kecil semuanya dapat beregenerasi menghasilkan embrio somatik, sedangkan klon KW 165 dan KW 163 dengan ukuran eksplan sedang menunjukkan respon yang paling rendah dengan persentase eksplan menghasilkan embrio rata-rata sebesar $13,5 \%$ dan $6,7 \%$. Jika diurutkan dari 5 klon kakao yang diuji, dimulai dari yang paling responsif adalah: Sca $6, \mathrm{RCC} 72, \mathrm{KW} 162, \mathrm{KW}$ 163 dan KW 165. dan Hasil ini sesuai dengan hasil penelitian Winarsih et al., (2002), bahwa klon Sca 6 menunjukkan respon yang paling baik dalam menghasilkan embrio.

Tahap Multiplikasi. Tabel 5 menunjukkan bahwa terdapat interaksi antara jenis eksplan dan ukuran eksplan terhadap jumlah embrio yang terbentuk. Klon Sca 6 dan RCC 72 menunjukkan klon yang paling responsif dengan semua ukuran terhadap jumlah embrio yang terbentuk. Klon Sca 6 dan RCC 72 dengan ukuran eksplan besar, sedang eksplan kecil juga memberikan respon yang sama terhadap jumlah embrio yang terbentuk. sedangkan klon KW 163 dan KW 165 dengan ukuran eksplan sedang menunjukkan respon yang paling rendah terhadap jumlah embrio yang terbentuk. Perbedaan respon antarklon yang diuji disebabkan adanya faktor genetis dan adanya respon yang berbeda dalam penyerapan zat pengatur tumbuh oleh setiap klon
(Masseret et al., 2008; Winarsih et al., 2003), sedangkan untuk klon-klon lain yang memberikan respon rendah diduga karena keseimbangan konsentrasi zat pengatur tumbuh di dalam media tidak sesuai.

Klon RCC 72 menghasilkan rata-rata jumlah embrio terbanyak yaitu 2,6, Sca 6 pada urutan kedua dengan jumlah embrio 2,4 per eksplan, kemudian berturut-turut diikuti oleh klon KW $163(1,8)$, KW $162(1,4)$ dan KW $165(1,0)$. Urutan tingkat kemudahan dalam proses diferensiasi tersebut adalah klon RCC 72, KW 162, Sca 6, KW 163 dan KW 165. Jika persentase eksplan yang dapat membentuk embrio tinggi, maka peluang untuk mendapat jumlah embrio somatik juga lebih banyak. Di samping lamanya inkubasi ada beberapa faktor yang menentukan jumlah embrio somatik yang dihasilkan, yaitu banyaknya eksplan yang menghasilkan embrio dan derajat multiplikasi embrio somatik dari tiap eksplan tersebut. Keduanya saling berinteraksi menghasilkan satuan jumlah embrio somatik.

Embrio somatik yang dihasilkan pada media induksi kemudian dipindahkan ke media multiplikasi untuk mendapatkan embrio somatik sekunder dalam jumlah yang lebih banyak. Terdapat pengaruh yang nyata pada interaksi antara jenis eksplan dengan ukuran eksplan terhadap jenis embrio somatik yang terbentuk (globular dan torpedo memanjang) per eksplan. Dari kelima bentuk embrio somatik (globular, hati, torpedo, torpedo memanjang dan kotiledon) semuanya menunjukkan hasil yang berbeda-beda, meskipun untuk fase hati dan kotiledon hanya faktor jenis eksplan yang berbeda nyata dan fase torpedo tidak berpengaruh nyata untuk interaksi dan faktor tunggal.

Tabel 4. Presentase eksplan menghasilkan embrio (25 MST)

\begin{tabular}{lccccc}
\hline \multicolumn{1}{r}{ Ukuran Embrio } & Sca 6 & KW 162 & KW 163 & KW 165 & RCC 72 \\
\cline { 2 - 6 } Besar & $100 \mathrm{~d}$ & $93,4 \mathrm{~cd}$ & $100 \mathrm{~d}$ & $53,4 \mathrm{bc}$ & $93,4 \mathrm{~cd}$ \\
Sedang & $100 \mathrm{~d}$ & $100 \mathrm{~d}$ & $6,7 \mathrm{a}$ & $13,5 \mathrm{a}$ & $100 \mathrm{~d}$ \\
Kecil & $100 \mathrm{~d}$ & $86,6 \mathrm{~cd}$ & $39,8 \mathrm{ab}$ & $66,6 \mathrm{bcd}$ & $100 \mathrm{~d}$ \\
\hline
\end{tabular}

Keterangan: angka-angka pada kolom yang diikuti oleh huruf yang sama menunjukkan berbeda tidak nyata pada uji BNJ $5 \%$

Tabel 5. Jumlah embrio somatik per eksplan (25 MST)

\begin{tabular}{lccccc}
\hline \multirow{2}{*}{ Ukuran Embrio } & Sca 6 & KW 162 & KW 163 & KW 165 & RCC 72 \\
\cline { 2 - 6 } Besar & $1,4 \mathrm{abc}$ & $1,0 \mathrm{ab}$ & $1,8 \mathrm{bc}$ & $0,8 \mathrm{ab}$ & $1,4 \mathrm{abc}$ \\
Sedang & $2,40 \mathrm{c}$ & $1,4 \mathrm{abc}$ & $0,2 \mathrm{a}$ & $0,2 \mathrm{a}$ & $2,6 \mathrm{c}$ \\
Kecil & $1,6 \mathrm{bc}$ & $1,4 \mathrm{abc}$ & $1,4 \mathrm{abc}$ & $1,0 \mathrm{ab}$ & $2,0 \mathrm{bc}$ \\
\hline
\end{tabular}

Keterangan: angka-angka pada kolom yang diikuti oleh huruf yang sama menunjukkan berbeda tidak nyata pada uji BNJ $5 \%$


Tahap Perakaran. Embrio somatik yang sudah mencapai fase torpedo memanjang dan kotiledon (Gambar 1a) selanjutnya dipindah ke media perakaran untuk menumbuhkan plantlet. Setelah dua minggu pada media perakaran, ES fase torpedo memanjang dan kotiledon berkembang menjadi plantlet yang ditandai dengan tumbuhnya akar dan daun primer (Gambar 1b). ES fase torpedo memanjang dan kotiledon yang berkembang menjadi plantlet hanya klon RCC 72 dan SCA 6 saja, sedangkan klon KW 162, KW 163 dan KW 165 mengalami kematian pada semua ulangan karena kontaminasi dan pencoklatan. Meskipun ada sebagian yang bertahan hidup, tidak beregenerasi melalui embrio somatik, tetapi beregenerasi seperti embrio zigotik yang dikulturkan untuk ditumbuhkan melalui proses organogenesis. Kesulitan memperoleh planlet berakar hasil kultur jaringan juga di alami oleh Bindu dan Mallika (2008).

Tabel 6 menunjukkan klon RCC 72 ukuran kecil memberikan respon paling baik pada jumlah embrio berakar dan panjang akar. Respon terhadap pertumbuhan akar bervariasi antarklon yang diuji. Penelitian ini sejalan dengan penelitian Winarsih et al., (2003), yang menyebutkan bahwa klon RCC 72 dan SCA 6 mempunyai respon paling baik dalam pertumbuhan akar dan tunas.

Selain ditentukan oleh penambahan air kelapa dan auksin, pembentukan embrio aseksual juga dipengaruhi oleh tingkat perkembangan embrio zigotik yang dikulturkan. Kemampuan embrio zigotik berwarna putih untuk membentuk embrio aseksual tampaknya ada hubungannya dengan pertumbuhan yang cepat, karena pada umumnya embrio muda yang berwarna putih yang berarti lebih muda jauh lebih mudah menghasilkan embrio aseksual daripada embrio dewasa yang berwarna merah kecoklatan yang berarti lebih tua.

Tabel 7 menunjukkan bahwa klon RCC 72 ukuran kecil memberikan respon yang paling baik juga pada jumlah daun, panjang daun, jumlah tunas serta tinggi tanaman. Hal ini disebabkan karena tingkat kemudahan dalam proses reproduksi dapat menggambarkan tingkat kemudahan dalam proses perkecambahan dan perkembangan selanjutnya menjadi plantlet (Winarsih et al., 2002). ES yang telah beregenerasi menjadi plantlet, kemudian berkembang membentuk daun-daun baru.

Tahap Pra Aklimatisasi. Setelah delapan bulan di dalam botol kultur, plantlet dengan tinggi $4-5 \mathrm{~cm}$ dan mempunyai satu pasang daun yang berwarna hijau gelap mengkilap (Gambar 1c) dipindahkan ke tahap pra aklimatisasi yaitu tahap sebelum diletakkan di rumah kaca. Plantlet yang ditanam dalam gelas aqua dengan media steril campuran tanah, pupuk kandang dan pasir juga sebagian menggunakan sekam steril, hanya mampu bertahan hidup selama 20 hari. Hal ini kemungkinan disebabkan media pra aklimatisasi terlalu

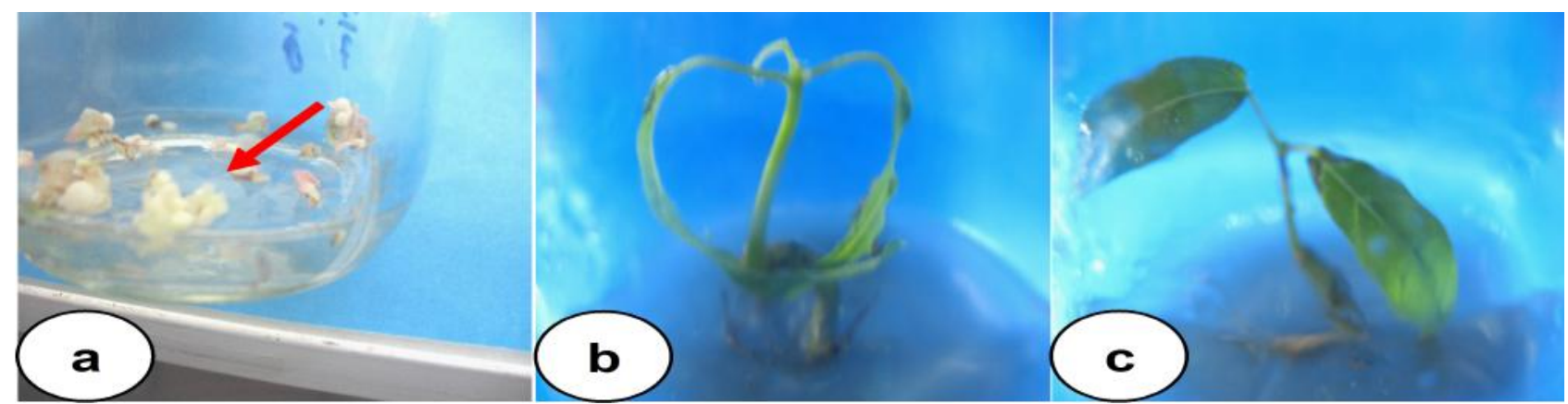

Gambar 1. (a.) Embriosomatik, (b) Planlet bertunas dan (c). Klon RCC 72 hasil ES yang sudah menjadi plantlet

Tabel 6. Rata-rata jumlah akar dan panjang akar (32 MST)

\begin{tabular}{|c|c|c|}
\hline \multirow{2}{*}{ Perlakuan } & \multicolumn{2}{|c|}{ Parameter Pengamatan } \\
\hline & Jumlah Akar & Panjang Akar \\
\hline Klon Sca 6 Besar & $0,0 \mathrm{a}$ & $0,0 \mathrm{a}$ \\
\hline Klon Sca 6 Sedang & $0,4 \mathrm{a}$ & $0,1 \mathrm{a}$ \\
\hline Klon Sca 6 Kecil & $0,4 \mathrm{a}$ & $0,2 \mathrm{a}$ \\
\hline Klon RRC 72 Besar & $0,0 \mathrm{a}$ & $0,0 \mathrm{a}$ \\
\hline Klon RRC 72 Sedang & $0,0 \mathrm{a}$ & $0,0 \mathrm{a}$ \\
\hline KIon RRC 72 Kecil & $1,6 \mathrm{~b}$ & $2,9 \mathrm{~b}$ \\
\hline
\end{tabular}


Tabel 7. Rata-rata jumlah daun, jumlah tunas, panjang daun dan tinggi tanaman (32 MST)

\begin{tabular}{lcccc}
\hline \multicolumn{1}{c}{ Perlakuan } & \multicolumn{4}{c}{ Parameter Pengamatan } \\
\cline { 2 - 4 } Klon Sca 6 Besar & Jumlah Daun & Jumlah Tunas & Panjang Daun & Tinggi Tan \\
Klon Sca 6 Sedang & $0,2 \mathrm{a}$ & $0,0 \mathrm{a}$ & $0,1 \mathrm{a}$ & $0,8 \mathrm{ab}$ \\
Klon Sca 6 Kecil & $0,2 \mathrm{a}$ & $0,0 \mathrm{a}$ & $0,1 \mathrm{a}$ & $1,7 \mathrm{bc}$ \\
Klon RRC 72 Besar & $0,6 \mathrm{a}$ & $0,2 \mathrm{a}$ & $0,4 \mathrm{a}$ & $2,2 \mathrm{bc}$ \\
Klon RRC 72 Sedang & $0,0 \mathrm{a}$ & $0,0 \mathrm{a}$ & $0,0 \mathrm{a}$ & $0,0 \mathrm{a}$ \\
Klon RRC 72 Kecil & $0,0 \mathrm{a}$ & $0,0 \mathrm{a}$ & $0,0 \mathrm{a}$ & $0,0 \mathrm{a}$ \\
Keterangan: angka-angka pada kolom yang diikuti oleh huruf yang sama menunjukkan berbeda tidak nyata pada uji BNJ 5\%
\end{tabular}

padat, kondisi lingkungan ruang kultur (inkubasi) yang berdekatan dengan tanaman kultur yang kontaminasi, sehingga jamur cepat menyebar juga faktor fisik yang belum optimum. Pemindahan plantlet dari kondisi in vitro ke kondisi in vivo merupakan salah satu tahap kritis bagi keberhasilan perbanyakan kultur jaringan. Plantlet hasil perbanyakan in vitro juga peka terhadap perubahan lingkungan yang drastis karena stomatanya belum berfungsi dengan baik, lapisan lilin daun sangat tipis dan rongga mesofilnya banyak.

\section{KESIMPULAN}

Klon RCC 72 merupakan klon yang paling responsif (data untuk semua parameter). Beberapa eksplan klin RCC 72 yang diuji dapat beregenerasi menjadi plantlet. Sedangkan Klon KW 165 memberikan respon terendah untuk semua parameter.

Untuk ukuran eksplan embrio zigotik kakao, ukuran kecil $(2-5 \mathrm{~cm})$ berpengaruh nyata pada jumlah embrio berakar dan jumlah embrio bertunas pada media perakaran.

\section{UCAPAN TERIMA KASIH}

Penelitian ini dibiayai oleh proyek KKP3T 2008. Terimakasih diucapkan kepada ICCRI dan Politeknik Negeri Jember atas bantuan klon-klon kakao yang digunakan dalam penelitian.

\section{DAFTAR PUSTAKA}

Alemanno, L., Garzon, I., Oliver, G., Dedieu, F., Paulin, D., D'Hauthuile, A., Wapo, L. \& Amores, F. 2007. Plant production by somatic embryogenesis from genotypes selected for agronomic traits in Ivory Coast and Ecuador [Poster]. Prosiding 14th International Cocoa Research Conference, 13-18 October 2003, Accra, Ghana-Montpellier: Cirad, 2003. http://publications. cirad.fr/une notice.php?dk=515850 (17 April 2009).

Alemano, L., Ramos, T., Gargadenec, A., Andary, C. \& Ferriere, N. 2003. Localization and identification of phenolic compounds in Theobroma cacao $L$. somatic embryogenesis. Annals of Botany 92: 613-623.
Anonim. 2008. Revitalisasi kakao didukung bibit embriogenesis somatik. http://www.sinartani. com/iptek/revitalisasi-kakaodidukung-bibit-embriogenesis-somatik (13 Nopember 2008).

Bindu, M.R. \& Mallika, V.K. 2008. Micrografting in cocoa (Theobroma cacao L.). Internat. J. agric. Sci 4(2): 601603.

Funek, D., Kasran, R., Lock, T.C., Johnsiul, L., Mohammed, A., Hartney, V., Yusof, M.M., Lamin, K. \& Tong, L.M. 2007. Biotechnology Research by the Malaysian Cocoa Board: Propagation by somatic embryogenesis. http:// www.koko.gov.my/CocoaBioTech/INGWorkshop(143148).html (7 April 2007).

Issali, A.E., Traoré, A., Ngoran, J.A.K., Koffi, E.K. \& Sangaré, A. 2009. Relationship between some phenological parameters and somatic embryogenesis in Theobroma cacao L. J. Crop Sci. Biotech 11(1): 23-30.

Issali, A.E., Abdoulaye Traoré, Jean Louis Konan, Joseph Mpika, Emile Minyaka, Jeanne Andi Kohi Ngoran. \& Abdourahamane Sangaré. 2010. Relationship between five climatic parameters and somatic embryogenesis from sporophytic floral explants of Theobroma cacao L. African Journal of Biotechnology 9(40): 6614-6625.

Li, Z., Traore, A., Maximova, S. \& Guiltinan, M.J. 1998. Somatic embryogenesis and plant regeneration from floral explants of cacao (Theobroma cacao L.) using Thidiazuron. Department of Horticulture. College of Agricultural Sciences. The Pennsylvania State University Park. Pennsylvania. 16802-4200.

Lopez-Baez, O., Helena, B., Albertus, E. \& Vincent, P. 1993. Embriogenesis somatique de cacaoyer Theobroma Cacao la portir de pieces florales. C.R. Acad. Sci. Paris, Science de lavie/Life sciences 316: 579-584.

Mark, G.J. \& Maximova, S.N. 2000. Recent Advance in The Tissue Culture Of Cocoa From Somatic Embryos to Bentwood Gardens. ACRI Molecular Biology Laboratory. Tyson Building. The Pennsylvania State University. University Park. PA. 16802.

Masseret, B., Vachet, C., Florin, B., Gianforcaro, M., Fillodeau, A., Brulard, E., Bouquet, J.F., Alvarez, M. \& Broun, P. 2008. Propagation of Cocoa (Theobroma cacao L.) by Somatic Embryogenesis and Field Performance of the Trees. Nestle R \& D Centre, Tours, France.

Mayolo, G.A., Maximova, S.N., Pishak, S. \& Guiltinan, M.J. 2003. Moxalactam as a counter selection antibiotic for Agrobacterium mediated transpormation and its possitive effect on Theobroma cacao somatic embryogenesis. Plant Science 164: 607-615

Oktavia, F., Siswanto., Budiani, A. \& Sudarsono. 2003. Embriogenesis somatik langsung dan regenerasi plantlet kopi arabika (Coffea arabica) dari berbagai eksplan. Menara Perkebunan, 71(2): 44-55.

Oliveira Santos, M., Romano, E., Yotoko, K.S.C., Tinoco, M.L.P., Dias, B.B.A. \& Araga o, F.J.L. 2005. Characterisation of the cacao somatic embryogenesis receptor-like kinase (SERK) gene expressed during somatic embryogenesis. Plant Sci. 168: 723-729.

Priyono, Matsaleh. \& Suhendi, D. 2000. Daya regenerasi dan morfisme pertumbuhan bibit hasil kultur daun ortotrop dan 
plagiotrop Coffea canephora melalui embriogenesis somatik. Pelita Perkebunan 16 (2): 65-74.

Luisa, F. Rojas, Julián Londoño, Adriana, M. Gallego, Andrea, L. Herrera, Carolina Aguilera. \& Lucía Atehortúa. 2008. Total polyphenols analysis of mature seeds and tissue cultures of some Colombian cocoa varieties. Actu Biol. [online]. 30(89):117-123. http:// www.scielo.unal.edu.

scielo.php?script $=$ sci_arttext $\&$ pid $=$ S0304-35842008000 200001\&lng=en\&nrm=iso (31 Maret 2011).

Tan, C.L. \& Furtek, D.B. 2003. Development of an in vitro regeneration system for Theobroma cacao L. from mature tissues. Plant Sci, 164: 407-412.
Wahyudi T., Panggabean, R. \& Pujiyanto. 2008. Panduan Lengkap Kakao, Manajemen Agribisnis dari Hulu hingga Hilir. Jakarta; Penebar Swadaya.

Winarsih, S, Santoso, D. \& Wardiyati, T. 2002. Embriogenesis somatik dan regenerasi dari eksplan embrio zigotik kakao (Theobroma cacao L). Pelita Perkebunan 18(3): 99-108.

Winarsih, S., Santoso, D. \& Wardiyati, T. 2003. Embriogenesis somatik dan regenerasi tanaman pada kultur in vitro organ bunga kakao. Pelita Perkebunan 19(1): 1-16. 